\title{
The proline-rich peptide Bac7(1-35) reduces mortality from Salmonella typhimurium in a mouse model of infection
}

\author{
Monica Benincasa ${ }^{+1}$, Chiara Pelillo¹, Sonia Zorzet ${ }^{1}$, Chiara Garrovo², Stefania Biffi2, Renato Gennaro ${ }^{1}$ and \\ Marco Scocchi*1
}

\begin{abstract}
Background: Bac7 is a proline-rich peptide with a potent in vitro antimicrobial activity against Gram-negative bacteria. Here we investigated its activity in biological fluids and in vivo using a mouse model of S. typhimurium infection.

Results: The efficacy of the active 1-35 fragment of Bac7 was assayed in serum and plasma, and its stability in biological fluids analyzed by Western blot and mass spectrometry. The ability of the peptide to protect mice against Salmonella was assayed in a typhoid fever model of infection by determination of survival rates and bacterial load in liver and spleen of infected animals. In addition, the peptide's biodistribution was evaluated by using time-domain optical imaging. Bac7(1-35) retained a substantial in vivo activity showing a very low toxicity. The peptide increased significantly the number of survivors and the mean survival times of treated mice reducing the bacterial load in their organs despite its rapid clearance.

Conclusions: Our results provide a first indication for a potential development of Bac7-based drugs in the treatment of salmonellosis and, eventually, other Gram-negative infections. The in vivo activity for this peptide might be substantially enhanced by decreasing its excretion rate or modifying the treatment schedule.
\end{abstract}

\section{Background}

The spread of multi-resistant bacterial pathogens poses a serious threat to the global society in light of commonly appearing hospital- and community-acquired drug-resistant infections. It is therefore urgent to search for new potent antimicrobial agents coping with arising pathogen invasion and, at the same time, minimising the probability of resistance induction in bacteria.

Antimicrobial peptides (AMPs) are widely recognized as promising alternatives to the currently used antibiotics and fungicides [1,2]. AMPs are widespread in living organisms and constitute an important component of innate immunity to microbial infections [3]. In mammals, they are produced by granulocytes, macrophages and most epithelial cells $[4,5]$. Amino-acid sequences of the vast majority of AMPs share cationic and amphipathic

\footnotetext{
* Correspondence: mscocchi@units.it

1 Department of Life Sciences, University of Trieste, Via Giorgieri 1, 34127

Trieste, Italy

+ Contributed equally

Full list of author information is available at the end of the article
}

properties that allow their insertion into lipid bilayers and can lead to alteration of biological membrane functions [6]. Initial characterization studies linked these properties to antimicrobial killing activity. However, further data indicated that this is not the only mode of action and that more subtle mechanisms might mediate the interaction with, and effect on target microbes, as well as the specificity and toxicity of peptides.

The proline-rich peptides (PRPs) are a distinctive group of AMPs, isolated in different animal sources, which display an unusually high content of proline and arginine residues in their sequences $[7,8]$. These peptides show a spectrum of activity limited to Gram-negative bacteria and appear to have a stereospecific mode of action mediated by the internalization of the peptides into the cytoplasm without extensive membrane damaging effects [7].

Bac7 is a linear, 60-residue proline-rich peptide of bovine origin corresponding to the $\mathrm{C}$-terminal antimicrobial domain of a specific protein precursor of cathelicidin family [9]. Previous studies demonstrated that Bac7, 
and its C-terminal truncated form Bac7(1-35), have a potent in vitro activity against many Gram-negative bacteria including Enterobacteriaceae, particularly Salmonella spp., and the genera Pseudomonas, Acinetobacter, and Sinorhizobium [10-12], while it is inactive against most of the Gram-positive bacteria. Bac7(1-35) is also active against multi-resistant clinical isolates [10] and is able to neutralize endotoxin in experimental rat models of Gram-negative septic shock [13]. In contrast to most AMPs, this peptide is not toxic to mammalian cells at concentrations well above those effective against microbes $[13,14]$. In this respect, Bac7(1-35) is internalized into eukaryotic cells through a pinocytic process $[14,15]$, but enters bacterial cells through a mechanism mediated by the membrane protein SbmA/BacA $[12,16]$. These features suggest that Bac7 and its fragments might be used in vivo without being toxic to the host and be effective also against intracellular pathogens.

Despite the high potential of many AMPs as antimicrobial agents [17], in most cases, their residual toxicity towards host cells and their rapid degradation and/or inhibition by components of biological fluids represent a real obstacle to their development as therapeutic molecules $[18,19]$.

In this study we investigated the in vitro activity of Bac7(1-35) in a more physiological context, such as in murine serum and plasma, and the in vivo potential in a murine infection model of typhoid fever. Results indicate that the peptide remains substantially active at the site of infection and reduces significantly the mortality of infected animals despite its rapid clearance.

\section{Results and Discussion}

\section{Antibacterial activity of Bac7(1-35) in serum or plasma}

Previous results showed that Bac7(1-35) has a potent in vitro activity against Gram-negative bacteria [10]. Before testing whether this peptide can also be active in vivo, we assayed its antibacterial activity in vitro in the presence of body fluid components. When killing kinetics assays were performed in the presence of $66 \%$ murine plasma or serum, the activity of Bac7(1-35) towards Salmonella enterica serovar Typhimurium was reduced although still detectable (Figure 1). In particular, after 1h-incubation with serum or plasma, Bac7(1-35) $(10 \mu \mathrm{M})$ reduced the number of CFU by $0.5-1 \log v s 2.5 \log$ detected in the absence of these biological fluids. To obtain a comparable reduction of CFU without the presence of plasma/serum, $1 \mu \mathrm{M}$ peptide should be used. At longer incubation times, the activity of the proline-rich peptide seemed further inhibited, especially by murine serum (Figure 1). We also assayed the effects of serum albumin, the most abundant protein in blood, on the peptide activity. In contrast to what observed for other AMPs [19], the bactericidal activity of Bac7(1-35) did not change upon addition of 40

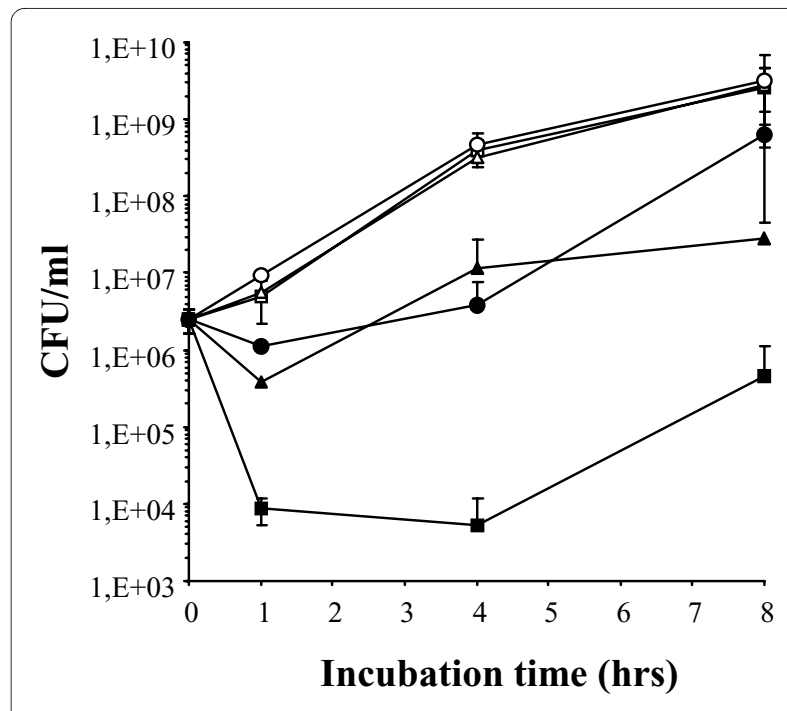

Figure 1 Antimicrobial activity of $\operatorname{Bac7(1-35)~in~the~presence~of~}$ biological fluids. Kinetics of the bactericidal activity of $10 \mu \mathrm{M} \mathrm{Bac7(1-}$ 35) against S. enterica ATCC 14028 in the absence (filled squares) or in the presence of $66 \%$ murine serum (filled circles), or $66 \%$ murine plasma (filled triangles). Bacterial growth without peptide is indicated by empty symbols. Results represent the mean \pm SD of three independent determinations performed in triplicate.

$\mathrm{mg} / \mathrm{mL} \mathrm{BSA}$, a concentration corresponding to that present in the blood (data not shown).

\section{Stability of Bac7(1-35) in serum and plasma}

Inhibition of the peptide due to enzymatic degradation by blood proteases was taken into account to explain the reduced activity of Bac7(1-35) in biological fluids. The stability of Bac7(1-35) was therefore evaluated by incubating the peptide up to $24 \mathrm{~h}$ with murine plasma or serum followed by Western blot analysis. Immunodetection indicated a slow and progressive reduction of the band corresponding to intact Bac7(1-35), which disappeared after $24 \mathrm{~h}$-incubation in serum (Figure $2 \mathrm{~A}$ ). The degradation of Bac7(1-35) in plasma was slower (Figure $2 \mathrm{~A})$, suggesting that the activation of proteases of the coagulation cascade in serum may contribute to the faster peptide degradation in this medium. LC-MS analysis indicated that the amount of intact Bac7(1-35) in murine serum decreases by $10 \%$ after $1 \mathrm{~h}$ of incubation and that the peptide was almost completely degraded after $8 \mathrm{~h}$ (Figure $2 \mathrm{~B}$ and $2 \mathrm{C}$ ). The degradation process is slower in plasma than in serum, (Figure $2 \mathrm{~B}$ and $2 \mathrm{C}$ ), confirming the result observed in the Western blot analysis, while in PBS alone, no peptide degradation was observed even after several days of incubation at $37^{\circ} \mathrm{C}$.

No fragments of Bac7(1-35) were detected by LC-MS analysis. This may due to generation of hydrophilic fragments of a few residues by responsible protease(s), which are not detectable by either anti-Bac7 antibodies or LCMS. Enzymes such as trypsin-like serine proteases, which 

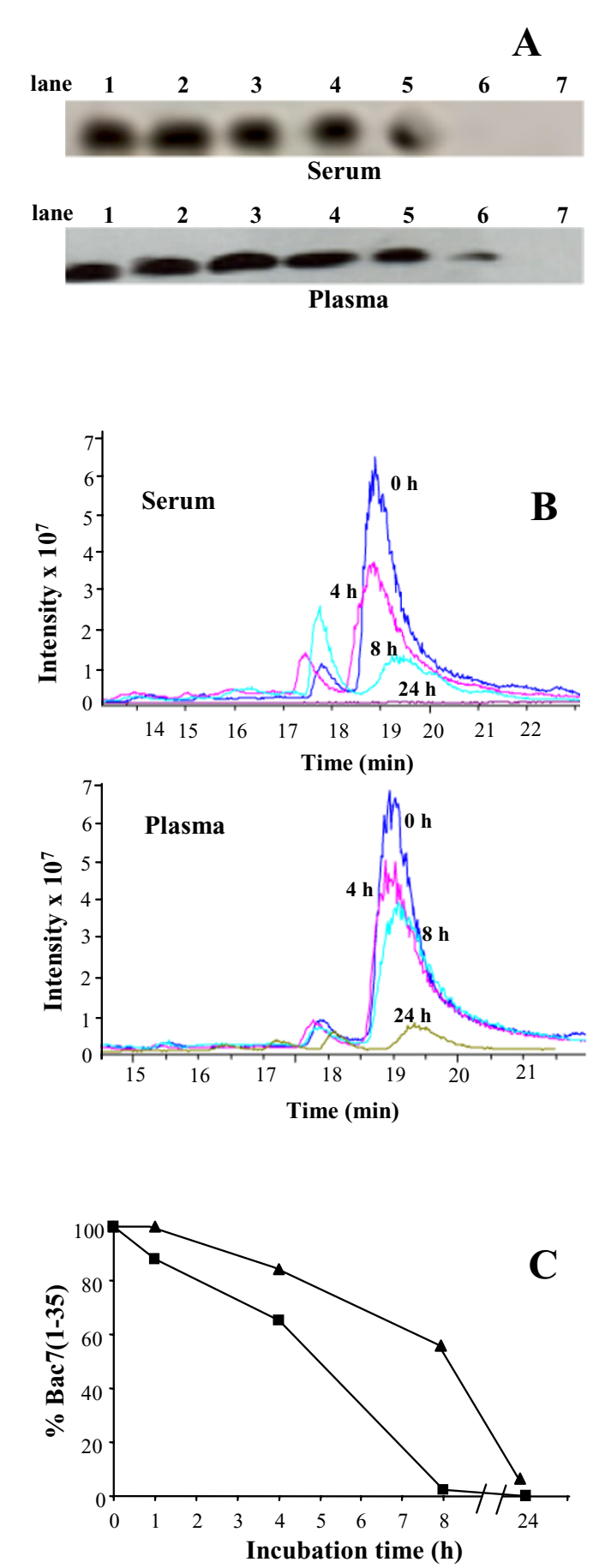

Figure 2 Bac7(1-35) stability in blood fractions. (A) Western blot analysis of Bac7(1-35) incubated for different times at $37^{\circ} \mathrm{C}$ in $25 \%$ murine serum or plasma. Lane 1: $0.5 \mu \mathrm{g} \mathrm{Bac7(1-35);} \mathrm{lanes} \mathrm{2-6:} \mathrm{Bac} \mathrm{7(1-35)}$ after incubation with murine serum or plasma for respectively $0,1,4,8$, 24 hrs; lane 7: serum or plasma alone. (B) MC-LC chromatograms of Bac7(1-35) incubated at $37^{\circ} \mathrm{C}$ in $25 \%$ murine serum or plasma. (C) The percentages of $\mathrm{Bac} 7(1-35)$ with respect to the $\mathrm{t}_{0}$ control were calculated following LC-MS analysis (see section Methods for further details) after incubation of the peptide with murine serum (filled squares) or plasma (filled triangles) for different times. may cleave at the many Arg residues present in the sequence of Bac7(1-35), might have this effect. However, these results clearly indicate that the peptide should be quite stable in blood and its degradation occurs only after several hours, suggesting that the decreased activity of $\mathrm{Bac7}(1-35)$ is only in part due to its degradation.

\section{In vivo toxicity}

As a first step to evaluate the therapeutic potential of Bac7(1-35), its in vivo toxicity was determined in Balb/c and CBA/Ca mice after injection via i.p. of increasing single peptide doses. No apparent toxic effect was observed when the peptide was administered i.p. up to $75 \mathrm{mg} / \mathrm{kg}$, but the mice receiving the highest peptide dose $(150 \mathrm{mg} /$ $\mathrm{kg}$ ) died 3 days post injection. This result confirms that Bac7(1-35) is much less toxic than other cathelicidinderived peptides such as those belonging to the $\alpha$-helical group [20] and, in this respect, it behaves similarly to insect proline-rich AMPs. For example, pyrrhocoricin protected mice against $E$. coli infection, and showed no toxicity up to the maximal applied dose i.v. of $50 \mathrm{mg} / \mathrm{kg}$. Drosocin is completely devoid of toxicity to healthy animals when used via i.v. at $100 \mathrm{mg} / \mathrm{kg}$ [8]. On the contrary, lytic peptides such as BMAP-27 and -28 are toxic via i.p. already at $10-15 \mathrm{mg} / \mathrm{kg}$ [20].

\section{In vivo Bac7(1-35) activity in a mouse model of typhoid fever}

The potential of Bac7(1-35) to protect mice from a bacterial challenge was tested by a mouse model of Salmonella infection. Infected mice develop a systemic disease characterized by rapid bacterial multiplication in the liver and spleen that resembles typhoid fever caused by Salmonella serovar Typhi in humans [21]. Cell-mediated immunity and macrophage activity play a key role in defence against murine salmonellosis, and it has been shown that these immune responses are lacking in Balb/c mice [22,23] so that also the antibiotic ciprofloxacin failed to prevent fatal S. typhimurium disease in this mouse strain [22]. For this reason, we preferred to use CBA/Ca mice that show a lower susceptibility to Salmonella infection [22] to study the antimicrobial properties of Bac7(1-35). Nevertheless, an acute infection may be induced by i.p. injection of less than a hundred of CFU/mouse. Male CBA/Ca mice were infected via i.p. with a lethal dose of $S$. typhimurium ATCC $14028\left(1 \times 10^{2} \mathrm{CFU} / \mathrm{mouse}\right)$, followed by i.p. injection of peptide at $30 \mathrm{mg} / \mathrm{kg}$. The number of survivors was monitored for 60 days and compared to that of control mice that only received the lethal bacterial challenge. The survival curves of untreated and peptide-treated mice are significantly different $(\mathrm{p}=0.01)$; the mean survival time of control mice was 10 days, while the treatment of infected mice with Bac7(1-35) increased the mean survival time to 24.5 days. It is worth noting that $36 \%$ of the 
infected mice treated with Bac7(1-35) were completely cured with respect to $0 \%$ survival for untreated animals (p $=0.04$ ) (Figure 3A).

In parallel to survival experiments, a group of mice was also analyzed for bacterial load at 3 days post-inoculation, when the infected animals did not show any visible sign of disease. Viable bacterial cells were counted in murine liver and spleen of infected mice and results are reported in Figure 3B. The number of viable bacterial cells in liver and spleen homogenates decreased significantly in the animals treated with the peptide at $30 \mathrm{mg} / \mathrm{kg}$, despite a
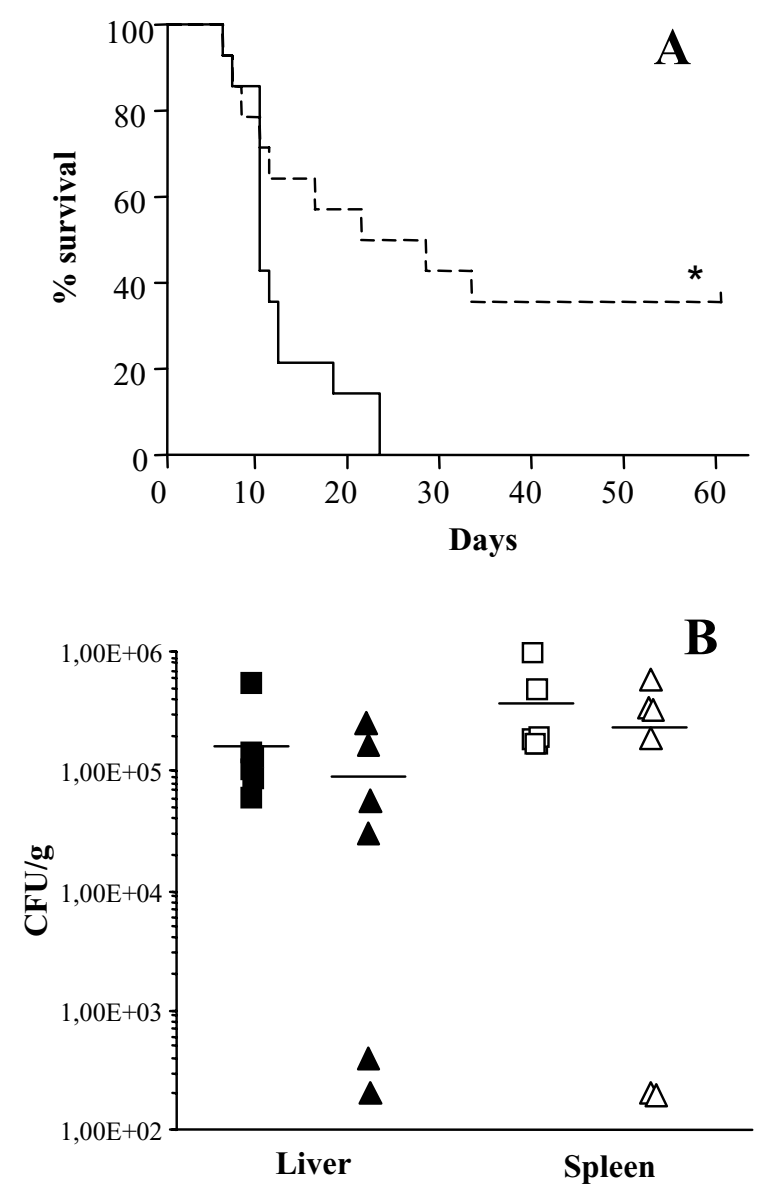

Figure $\mathbf{3}$ In vivo activity of Bac7(1-35). Survival curves (A) and viable bacterial counts in liver and spleen homogenates (B) of mice infected with S. enterica after treatment via i.p. with Bac7(1-35) are shown. CBA Ca mice were infected via i.p. with S. enterica ATCC 14028 (102 CFU/ mouse) and Bac7(1-35) at $30 \mathrm{mg} / \mathrm{kg}$ was immediately injected via i.p. after bacterial challenge (dotted line). Control mice were given $0.2 \mathrm{ml}$ of PBS (continuous line). Mice were monitored for survival over a 60day period after infection. ${ }^{*} p<0.05$ treated vs untreated mice. Three days after bacterial infection, untreated (squares) and peptide-treated (triangles) mice were killed, and liver (full symbols) and spleen (empty symbols) homogenates were prepared as described in section Methods. Results are expressed as number of CFU/g organ; bars represent the mean value for each group. remarkable variability in each group. In $1 / 3$ of the animals bacteria were undetectable in both the spleen and liver. This result is in keeping with the percentage of mice cured extrapolated by the survival curve (Figure 3A).

Given that i.p. injection of as few as 100 salmonellae is lethal for mice, the increased survival times and the eradication of the infection in $1 / 3$ of the peptide-treated animals is a promising result. In addition, the protective role showed by Bac7(1-35) suggests that the peptide may exert its bactericidal action also in infected cells, since $S$. typhimurium is an intracellular pathogen and Bac7(1-35) is able to penetrate host cells $[14,15]$.

\section{In vivo Time-Domain Optical Imaging}

Following the results with the mouse model of infection, we investigated the in vivo biodistribution of Bac7(1-35) by using a time-domain optical imaging instrument [24] and a derivative of Bac7(1-35), fluorescently labelled with the dye Alexa680, showing an antimicrobial activity comparable to that of the unlabelled peptide (data not shown).

The Bac7(1-35)-Alexa680 peptide shows a fast elimination kinetics after i.p. injection, characterized by a specific fluorescence intensity signal in the kidney first and then in the bladder. The compound reaches the kidney and the bladder in respectively 1 and 3 hours after the injection. The in vivo and ex vivo analyses performed after $24 \mathrm{~h}$ confirm that the compound has been totally excreted (Figure 4). These results suggest that the labelled compound does not accumulate in any particular organ except those involved in the elimination processes, kidney and bladder, which result completely free of Bac7(135)-Alexa680 one day after injection.

It is well known that mice eliminate drugs thought kidney much more quickly than humans [25]. As no nefrotoxic compounds causing renal dysfunction were used to alter pharmacokinetic parameters [25], the very rapid clearance of the peptide may likely have limited its activity against pathogens after injection in the animals. In the light of this observation, the antibiotic activity of Bac7(135) may be improved in the future by slowing the kinetics of its renal excretion.

\section{Conclusions}

In conclusion, with this study we have shown that Bac7(1-35) may exert antibacterial activity also in vivo, in a mouse model of infection resembling typhoid fever in humans. This model is particularly challenging in mice due to the extremely low lethal dose of $S$. typhimurium. Intraperitoneal injection of $\mathrm{Bac} 7(1-35)$ at $30 \mathrm{mg} / \mathrm{Kg}$ increased significantly the survival rate of infected mice and the mean survival times suggesting that it inactivates most of the inoculated bacteria in spite of a partial inhibition due to unknown blood components and a very fast renal excretion rate. 

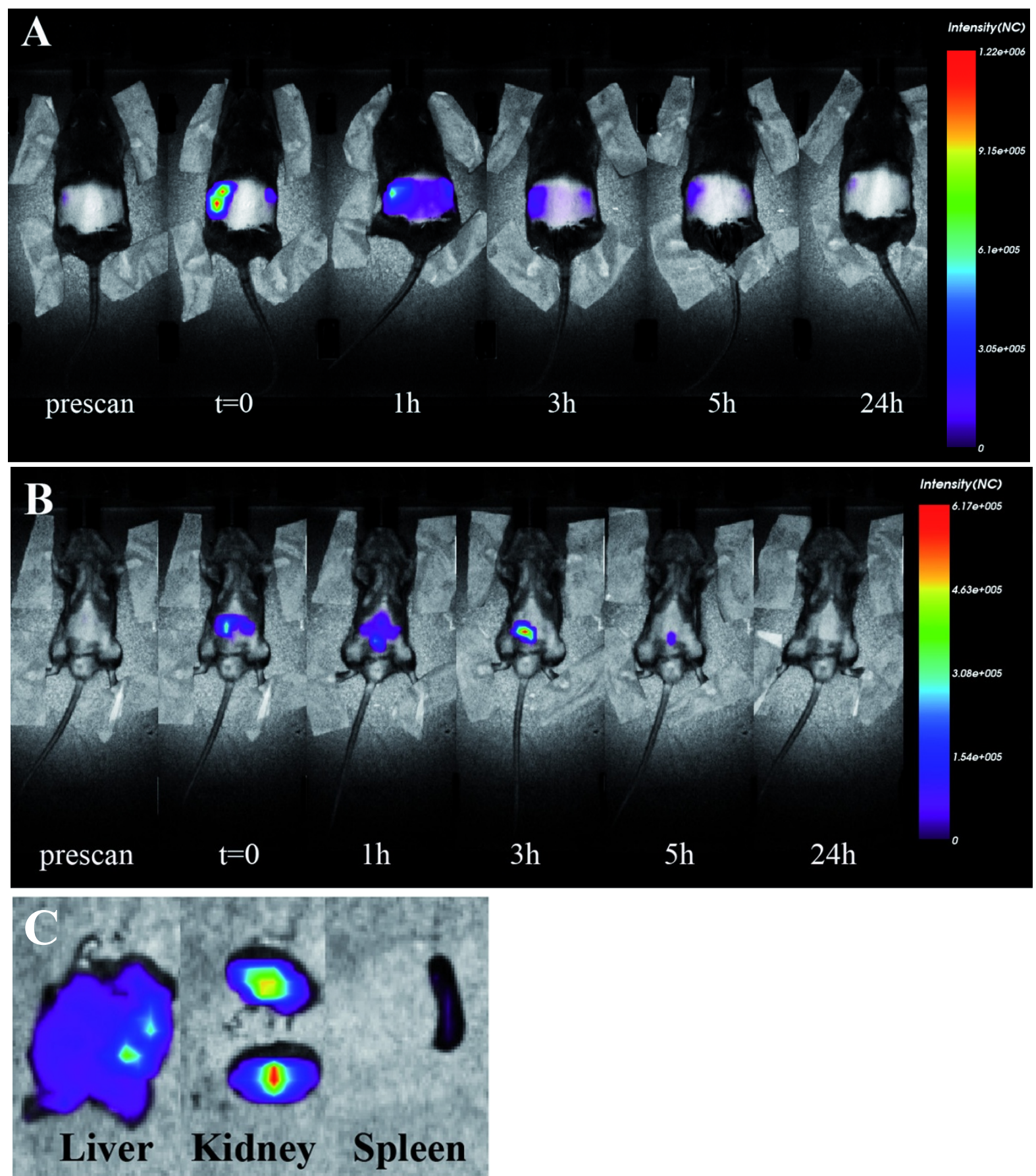

Figure 4 Biodistribution of Bac7(1-35)-Alexa680 in healthy mice after i.p. injection. (A) The animal was placed in prone position, fluorescence emission in regions of interest encompassing the kidneys were acquired at indicated times post-injection and normalized. (B) The animal was placed in supine position, fluorescence emission in regions of interest encompassing the thorax and abdomen was acquired at indicated times post-injection and normalized. (C) Exvivo images of organs at 5 hours after i.p. injection. Imaging of the organs was performed immediately after sacrifice: laser power and integration time were optimized while keeping constant scan step to compare fluorescence intensities after normalization. The images are representative of two independent experiments with comparable results. 
In the light of these observations, the results here reported provide encouraging evidence for a future development of a Bac7-based drug in the treatment of Gram-negative infections. Its in vivo efficacy might be improved by decreasing its clearance rate, for instance by conjugation of the peptide with a drug delivery system. Moreover, its effectiveness can also be improved by changing the treatment regimen, for example with repeated dosing. These studies are currently in progress.

\section{Methods}

\section{Peptide synthesis and labelling}

The N-terminal fragment 1-35 of Bac7 was synthesized, purified and stored as described [11]. Bac7(1-35) was fluorescently-labelled via linkage of the thiol-reactive dye ALEXA FLUOR $680 \mathrm{C}_{2}$-maleimide (Invitrogen, Carlsbad, CA) to a specifically added C-terminal cysteine residue. Briefly, the fluorophore ALEXA FLUOR $680(1 \mathrm{mg})$ was dissolved in $100 \mu \mathrm{L}$ DMSO, and added drop wise to 30 $\mathrm{mL}$ Na-phosphate buffer $10 \mathrm{mM}, \mathrm{pH}$ 7, under nitrogen bubbling in the dark. Four mg of Bac7(1-35)-Cys were dissolved in this solution; after $1 \mathrm{~h}$ incubation at room temperature with stirring, a new aliquot of peptide ( $4 \mathrm{mg}$ ) was added and the solution was left overnight at $4^{\circ} \mathrm{C}$. At the end of the incubation time, an excess of cysteine (10 $\mathrm{mg}$ ) was added in this solution to scavenge the excess of thiol-reactive reagent. The solution was left with stirring for $1-2 \mathrm{~h}$ and the labelled peptide was purified by RPHPLC.

\section{Antibacterial activity in serum and plasma}

Murine plasma obtained using 2\% (v/v) Na-citrate as an anticoagulant, and serum were prepared and stored at $20^{\circ} \mathrm{C}$ until use. The bactericidal activity of Bac7(1-35) against Salmonella enterica serovar Typhimurium ATCC 14028 was determined by a killing kinetics assay [11]. Mid-logarithmic phase S. enterica cultures were diluted in murine serum or plasma (66\% v/v final concentration) or BSA $\left(40 \mathrm{mg} / \mathrm{mL}\right.$ ) (Sigma) to give approximately $1 \times 10^{6}$ cells $/ \mathrm{ml}$, and incubated with $10 \mu \mathrm{M} \mathrm{Bac7(1-35)} \mathrm{in} \mathrm{a} \mathrm{shak-}$ ing water bath at $37^{\circ} \mathrm{C}$ for different times. Samples were withdrawn, diluted and plated to allow colony counts [11].

\section{Peptide stability in biological fluids}

To test the peptide stability in biological fluids, $120 \mu \mathrm{g}$ of Bac7(1-35) were incubated in $200 \mu \mathrm{L}$ of PBS containing $25 \%(\mathrm{v} / \mathrm{v})$ murine serum or plasma at $37^{\circ} \mathrm{C}$, or in PBS alone. At different times, aliquots of samples were diluted $1: 5$ in sample buffer (12\% SDS, 6\% dithiothreitol, $40 \%$ glycerol, $0.05 \%$ bromophenol blue, $150 \mathrm{mM}$ Tris- $\mathrm{HCl}, \mathrm{pH}$ 7), incubated for $15 \mathrm{~min}$ at $60^{\circ} \mathrm{C}$ and analyzed on a $16 \%$ Tricine/SDS gel. Proteins were then blotted onto nitrocellulose membrane (Whatman), and incubated overnight with shaking at $4{ }^{\circ} \mathrm{C}$ in $40 \mathrm{mM}$ Tris- $\mathrm{HCl}, \mathrm{pH} 7.5,5 \%$ nonfat milk, $0.05 \%$ Tween 20, $200 \mathrm{mM} \mathrm{NaCl}$ (blocking solution). Samples were incubated for $90 \mathrm{~min}$ with 1:1000 rabbit anti-Bac7(1-35) IgG, diluted in blocking solution, followed by a HRP-conjugated anti-rabbit IgG (SigmaAldrich). The ECL detection system (GE Healthcare) was used to develop the Western blots.

\section{LC-MS analysis}

Bac7 (1-35) peptide $(50 \mu \mathrm{g})$ was incubated in $250 \mu \mathrm{L}$ of PBS containing $25 \%(\mathrm{v} / \mathrm{v})$ of murine serum or plasma at $37^{\circ} \mathrm{C}$. At different time intervals $(0,1,2,4,8$ and $24 \mathrm{~h}$ ), aliquots of $25 \mu \mathrm{L}$ (corresponding to $5 \mu \mathrm{g}$ of peptide) were added to $65 \mu \mathrm{L}$ of cold $0.5 \%(\mathrm{v} / \mathrm{v})$ TFA in $\mathrm{H}_{2} \mathrm{O}$, kept on ice for $5 \mathrm{~min}$ and than centrifuged at $10.000 \times \mathrm{g}$ for $5 \mathrm{~min}$. The LC-MS analysis of supernatants were carried out as described [26], using a standard curve to calculate the peptide concentration.

\section{Animals}

Male Balb/c and CBA/Ca mice of approximately $20 \mathrm{~g}$ and 6 weeks of age were obtained from Harlan Laboratories (Udine, Italy) and maintained under pathogen-free conditions. All the experimental procedures were performed according to the guidelines of the European (86/609/ EEC) and the Italian (D.L.116/92 and subsequent addenda) laws and approved by the Italian Ministry of University and Research as well as by the Animal Experimentation Committee of the University Animal House.

\section{In vivo studies}

The in vivo toxicity of Bac7(1-35) was investigated by injecting mice via i.p. with increasing amounts of the peptide dissolved in apyrogen PBS (0.2 ml per mouse). The controls received the vehicle alone. Animal behavior and survival were monitored over a 14-day period.

Inocula containing $10^{2} \mathrm{CFU} /$ mouse of S. enterica ATCC 14028 , expected to result in $90-100 \%$ mortality in 4-6 days for Balb/c [27] and 10-18 days for CBA/Ca, were prepared by diluting log-phase bacterial cultures in sterile PBS. Ten mice were infected intraperitoneally and monitored for survival over a 60-day period after infection. Test peptide $(30 \mathrm{mg} / \mathrm{kg})$ was injected via i.p. after bacterial challenge. The choice of dose was based on preliminary data obtained with lower doses (data not shown) and on results reported in the literature for structurally similar peptides. Control mice were given $0.2 \mathrm{ml}$ of PBS. The experiment was repeated two times and comparable results were obtained. The analysis of survival curves was conducted using the Kaplan-Meyer method and successive statistical evaluation by the Logrank test. Significance of percentage differences among groups was assessed by using the Fisher exact test. Values of $\mathrm{p}<0.05$ were considered statistically significant. 


\section{Viable colony counts in murine liver and spleen homogenates}

Three days after bacterial infection, a group of 3 untreated and 3 peptide-treated mice were killed by cervical dislocation, and liver and spleen were removed. The organs were weighed, homogenized separately and dissolved in PBS. Suitable dilutions of $50 \mu \mathrm{L}$ of the homogenate in PBS were plated in duplicate on Mueller-Hinton agar (Difco). The plates were then incubated at $37^{\circ} \mathrm{C}$ overnight to allow colony counts. Results are expressed as number of CFU/g of organ. This assay was repeated two fold.

\section{Mice preparation and treatment for in vivo Time-Domain Optical Imaging}

The day before the treatment, healthy CBA mice were anesthetized by an intramuscular injection of a diluted mixture (1:5 in PBS) composed by $0.4 \mathrm{~mL}$ Zoletil 100 and $0.25 \mathrm{~mL}$ Rompun $2 \%$ ( $3 \mu \mathrm{L} / \mathrm{g}$ body weight), and shaved in the regions of interest to avoid laser scattering caused by hair. The following day, mice were anesthetized using a gaseous anaesthesia system (2Biological Instruments, Italy), based on isoflurane mixed to oxygen and nitrogen protoxide. Anaesthesia was first induced with $2 \%$ isoflurane in a pre-anaesthesia chamber and then the animals were placed inside the eXplore Optix in the presence of $1 \%$ isoflurane. Two mice were then injected intraperitoneally with $36.6 \mu \mathrm{g} /$ mouse of Bac7(1-35)-Alexa680, corresponding to 6.9 nmol ALEXA FLUOR 680 , one monitored in the abdominal region and the other in the renal region for 24 hours. A blank image was acquired before treatment of each animal and this was subtracted to the images of the treated animal. Experiment was repeated two times.

The small-animal time-domain eXplore Optix preclinical imager (GE Healthcare) was used in this study. In all imaging experiments, a $670 \mathrm{~nm}$ pulsed laser diode with a repetition frequency of $80 \mathrm{MHz}$ and a time resolution of 12 ps light pulse was used for excitation. The fluorescence emission at $700 \mathrm{~nm}$ was collected and detected through a fast photomultiplier tube and a highly sensitive time-correlated single-photon counting system. Twodimensional scanning regions of interest (ROI) were selected and the laser power, integration time and scan step were optimized according to the signal emitted. The data were recorded as temporal point-spread functions, and the images were reconstructed as fluorescence intensity and lifetime.

\footnotetext{
Authors' contributions

MB performed antimicrobial assays, in vivo studies, and contributed to write the manuscript. CP performed peptide' stability experiments, antimicrobial assays and helped to draft the manuscript. SZ participated in the design of the in vivo study and analysis of its results. CG and SB participated in biodistribution studies with in vivo Optical Imaging and analysis of the results. RG participated in study design and coordination and helped to edit the manuscript. MS con-
}

ceived of the study, drafted and wrote the manuscript. All authors have read and approved the final manuscript.

\section{Acknowledgements}

We thank Prof. Alessandro Tossi for critically reading the manuscript and the animal house staff of the University of Trieste for their assistance in maintaining the mice. This study was supported by grants from the Italian Ministry for University and Research (PRIN 2007), and from the Regione Friuli Venezia Giulia (grant under the LR 26/2005, art. 23 for the $R^{3} A^{2}$ network).

\section{Author Details}

1Department of Life Sciences, University of Trieste, Via Giorgieri 1, 34127 Trieste, Italy and 2Optical Imaging Laboratory, CBM, Area Science Park, Trieste, Italy

Received: 23 March 2010 Accepted: 23 June 2010

Published: 23 June 2010

\section{References}

1. Hancock RE, Sahl HG: Antimicrobial and host-defense peptides as new anti-infective therapeutic strategies. Nat Biotechnol 2006, 24(12):1551-1557.

2. Ajesh K, Sreejith K: Peptide antibiotics: an alternative and effective antimicrobial strategy to circumvent fungal infections. Peptides 2009, 30(5):999-1006

3. Lai Y, Gallo RL: AMPed up immunity: how antimicrobial peptides have multiple roles in immune defense. Trends Immuno/ 2009, 30(3):131-141.

4. Levy O: Antimicrobial proteins and peptides: anti-infective molecules of mammalian leukocytes. J Leukoc Biol 2004, 76(5):909-925.

5. Zanetti M: The role of cathelicidins in the innate host defenses of mammals. Curr /ssues Mol Biol 2005, 7(2):179-196.

6. Shai $Y$ : Mode of action of membrane active antimicrobial peptides. Biopolymers 2002, 66(4):236-248.

7. Gennaro R, Zanetti M, Benincasa M, Podda E, Miani M: Pro-rich antimicrobial peptides from animals: structure, biological functions and mechanism of action. Curr Pharm Des 2002, 8(9):763-778.

8. Otvos L: The short proline-rich antibacterial peptide family. Cell Mol Life Sci 2002, 59(7):1138-1150.

9. Scocchi M, Romeo D, Zanetti M: Molecular cloning of Bac7, a prolineand arginine-rich antimicrobial peptide from bovine neutrophils. FEBS Lett 1994, 352(2):197-200.

10. Benincasa M, Scocchi M, Podda E, Skerlavaj B, Dolzani L, Gennaro R: Antimicrobial activity of Bac7 fragments against drug-resistant clinical isolates. Peptides 2004, 25(12):2055-2061.

11. Podda E, Benincasa M, Pacor S, Micali F, Mattiuzzo M, Gennaro R, Scocchi M: Dual mode of action of Bac7, a proline-rich antibacterial peptide. Biochim Biophys Acta 2006, 1760(11):1732-1740.

12. Marlow VL, Haag AF, Kobayashi H, Fletcher V, Scocchi M, Walker GC, Ferguson GP: Essential role for the BacA protein in the uptake of a truncated eukaryotic peptide in Sinorhizobium meliloti. J Bacteriol 2009, 191(5):1519-1527.

13. Ghiselli R, Giacometti A, Cirioni O, Circo R, Mocchegiani F, Skerlavaj B, D'Amato G, Scalise G, Zanetti M, Saba V: Neutralization of endotoxin in vitro and in vivo by Bac7(1-35), a proline-rich antibacterial peptide. Shock 2003, 19(6):577-581.

14. Tomasinsig L, Skerlavaj B, Papo N, Giabbai B, Shai Y, Zanetti M: Mechanistic and functional studies of the interaction of a proline-rich antimicrobial peptide with mammalian cells. J Biol Chem 2006, 281(1):383-391.

15. Sadler K, Eom KD, Yang JL, Dimitrova Y, Tam JP: Translocating proline-rich peptides from the antimicrobial peptide bactenecin 7. Biochemistry 2002, 41(48):14150-14157.

16. Mattiuzzo M, Bandiera A, Gennaro R, Benincasa M, Pacor S, Antcheva N, Scocchi M: Role of the Escherichia coli SbmA in the antimicrobial activity of proline-rich peptides. Mol Microbio/ 2007, 66(1):151-163.

17. Marr AK, Gooderham WJ, Hancock RE: Antibacterial peptides for therapeutic use: obstacles and realistic outlook. Current Opinion in Pharmacology 2006, 6(5):468-472.

18. Bowdish DM, Davidson DJ, Hancock RE: A re-evaluation of the role of host defence peptides in mammalian immunity. Curr Protein Pept SCi 2005, 6(1):35-51. 
19. Maisetta G, Di Luca M, Esin S, Florio W, Brancatisano FL, Bottai D, Campa M, Batoni G: Evaluation of the inhibitory effects of human serum components on bactericidal activity of human beta defensin 3 . Peptides 2008, 29(1):1-6.

20. Benincasa M, Skerlavaj B, Gennaro R, Pellegrini A, Zanetti M: In vitro and in vivo antimicrobial activity of two alpha-helical cathelicidin peptides and of their synthetic analogs. Peptides 2003, 24(11):1723-1731.

21. Santos RL, Zhang S, Tsolis RM, Kingsley RA, Adams LG, Baumler AJ: Animal models of Salmonella infections: enteritis versus typhoid fever. Microbes Infect 2001, 3(14-15):1335-1344.

22. Easmon CS, Blowers A: Ciprofloxacin treatment of systemic salmonella infection in sensitive and resistance mice. J Antimicrob Chemother 1985, 16(5):615-619.

23. Takahashi M, Ushijima T, Seto A: Comparison of host responses induced by Salmonella typhimurium infection in genetically resistant and susceptible mice. J Med Microbiol 1990, 31(3):191-194.

24. Hassan M, Riley J, Chernomordik V, Smith P, Pursley R, Lee SB, Capala J, Gandjbakhche AH: Fluorescence lifetime imaging system for in vivo studies. Mol Imaging 2007, 6(4):229-236.

25. Mathe A, Komka K, Forczig M, Szabo D, Anderlik P, Rozgonyi F: The effect of different doses of cisplatin on the pharmacokinetic parameters of cefepime in mice. Lab Anim 2006, 40(3):296-300.

26. Antcheva N, Morgera F, Creatti L, Vaccari L, Pag U, Pacor S, Shai Y, Sahl HG, Tossi A: Artificial beta-defensin based on a minimal defensin template. Biochem J 2009, 421(3):435-447.

27. Campoy S, Jara M, Busquets N, Perez De Rozas AM, Badiola I, Barbe J: Role of the high-affinity zinc uptake znuABC system in Salmonella enterica serovar typhimurium virulence. Infect Immun 2002, 70(8):4721-4725.

doi: 10.1186/1471-2180-10-178

Cite this article as: Benincasa et al., The proline-rich peptide Bac7(1-35) reduces mortality from Salmonella typhimurium in a mouse model of infection BMC Microbiology 2010, 10:178

Submit your next manuscript to BioMed Centra and take full advantage of:

- Convenient online submission

- Thorough peer review

- No space constraints or color figure charges

- Immediate publication on acceptance

- Inclusion in PubMed, CAS, Scopus and Google Scholar

- Research which is freely available for redistribution

Submit your manuscript at www.biomedcentral.com/submit
C Biomed Central 